\title{
The Political Economy of Development In Nigeria: From The Colonial To Post Colonial Eras
}

\author{
osita-njoku agnes \\ Imo State University, Owerri, Imo State
}

\begin{abstract}
Most African countries were dominated by the Western countries. This is the resultant effect of their integration into the Western capitalist system. Nigeria's political economy has actually been driven by this integrative process to the point that it is now a problem achieving sustainable development no matter the efforts put in by the people. For the purpose of this study, information was gathered from secondary sources. The work was mainly based on review of relevant literature. Its focus is on the political economy of the development of the Nigerian society from the colonial to the post colonial eras. It examined the politics in development, the practice of this politics, the various developmental policies initiated in Nigeria, their implementation and level of success. The findings revealed that the political economy of the Nigerian society has experienced pitfalls resulting in an economy powered by visionless leaders, known for reckless spending, over-invoicing, diverting state finances into private account, thereby plunging the country into economic, social and political woes. Among other recommendations made, value re-orientation was proposed, disabusing the minds of the citizens from xenocentrism, wrong consumption patterns and import oriented culture.
\end{abstract}

KEY WORDS: Xenocentism, Sustainable Development, Consumption Patterns, Value Re - Orientation

\section{INTRODUCTION}

Nigeria has long been a case of interest for the study of political and economic development. The country is a great example of a post-colonial developing nation and its developmental history contains very important lessons on the political and economic retardation of the developing world.

Nigeria as a colonial entity enjoyed boom in the agricultural production and the mining of mineral resources such as iron ore, tin and coal. Foreign exchange was earned from the above resources. Each region had a comparative advantage through which it made its contributions to the center. The North for instance, was known for groundnut production, the West for her cocoa while the East Produced palm oil. During the colonial period, the politics of development was already manifested even with the construction of railway line through those areas that had products that could yield some revenue to the centre. According to Njoku (1998), the British political economy in Nigeria was along the line of economic exploitation of the colonized by foisting it into the orbit of the European capitalist economic system.

The operations and activities of the colonial authorities had no potential for stimulating economic development. For instance, British colonial "development" of indigenous palm produce industry was designed to meet increased demand by the international economy for vegetable oils for industrial use (Njoku, 1998). Ezeanyika (2010: 107) has maintained that the overall subordination of colonized nations by dominating foreign power is to "keep the colonized people in complete political subjection, and to maximize local human and natural resources".

By 1960 when Nigerian gained her political independence, the production of crude oil had changed the dynamics of the Nigerian political economy. Oil production is now the mainstay of the economy. According to Luqman and Lawal (2011) hardly could anything be written about the political economy of Nigeria without reference to its history of oil production. While the oil industry remains the mono-economic fulcrum of the Nigerian economy, its contribution to development and improvement of the living standards of Nigerians remain doubtful. The Nigerian case is simply a situation of poverty amidst plenty.

Instead of reinvesting the resources from excess crude oil sale into development of infrastructure like power, education, health, public transportation, water, housing and national security, among other sectors, what we witnessed is a political class deeply entrenched in corruption.

Nigeria has embarked on a plethora of post colonial developmental plans which equally have not achieved its desired objectives as stated in the second national development plan. This unpleasant situation can not augur well in the development of a stable political and economic institution necessary for building a strong and successful nation.

Data for this study were essentially gathered from secondary sources. In other words, its methodology is narrative, descriptive and analytical. It adopts an eclectic explanation of the concept of political economy and 
definition of development. It also explores the politics of development by the colonial authorities in Nigeria, post-colonial Nigeria development, conclusion and the way forward.

\section{POLITICAL ECONOMY X-RAYED}

The concept of political economy is not new in sociological and political discourse. It was developed in the $18^{\text {th }}$ century as the study of the economies of states, or politics, hence the term political economy. Today, political economy, where it is not used as a synonym for economics, may refer to very different things including Marxian analysis, applied public choice approaches emanating from the Chicago School and the Virginia school, or simply the advice given by economists to government or public on general economic policy or on specific proposals (Groonwegen, 2008). Maier (2008) suggests that a political economy approach interrogates economic doctrines to disclose their sociological and political premises. In summary, it regards economic ideas and behaviour, not as frameworks for analysis, but as believes and actions that must themselves be explained. Political economy is said to be concerned with the interactions between politics and economics. Thus, it deals with the interactions between economic policies and their social and political context. As put by Eboh (1999), political economy is an approach-cum-subject focusing on the structure of markets and government, the incentives, abilities and behaviour of economic agents, policy makers, civil servants and society at large. Bohon (2003), opined that sociologically, political economy generally explores the production, allocation and consumption of goods and services, including the role the state plays in these processes. It particularly emphasizes the social context that frames economic production, resources distribution and state action, typically a social context deeply marked by structural inequalities of class, ethno-racial identity, gender and nation.

It is instructive to note that the political economy of a country is pivotal to its economic dynamics and social system. Aregbeshola (2011) explained that while politics and the political process do not necessarily give rise to the social structure of people, the institutional framework, process and outcome of this existence do influence the course and outcomes of achievable socio-economic status of the nation and its people. For Henderson (2015) political economy challenges people to be critical and to cut through simplistic or propagandistic ways of seeing the world. In essence, political economy provides a more critical understanding of the foundation upon which all social and political life is built. Hence, offering a more nuance analysis than that offered by mainstream approaches that are patently failing a majority of people at the behest of a minority.

\section{THE CONCEPT OF DEVELOPMENT}

The concept of development can be said to be relative since, there cannot be one precise definition for it. As a result it has been defined by various people in different ways as shown below. The guideline to the fourth National Development plan (1980-85) attempted an explanation as thus; "that development has often been couched in terms of material things, rather than people, in terms of creation rather than revolution. True development it says must mean the development of man. It is also clear that development does not start with goals and things; it starts with people". The above definition actually regards man as the beneficiary of development efforts.

There are some other scholars who argue that development is not merely the construction of bridges and sky-scrapers in the major cities by the application of foreign technology. It is also the development of indigenous skills to exploit local resources for a sustained development process. According to Okoye (1985) development should imply not simply an increase in the productive capacity or income which may mean just growth without development, but major transformations in the socio-economic structures whose inequalities and rigidities resulting from outmoded systems, have tended to inhibit all-sided and even development of many third world societies. He went further to report that McNamara once emphasized that development is complex like life itself, and that 'development has been expressed in terms of growth of output. There is now the emerging awareness that the availability of work, the distribution of income and the quality of life are equally important measures of development'.

Okediji (1973), in Ibe (1989:20) summarized his definition of development as, 'A process of initiating societal change so as to improve the capability of the institution and values of community to meet the increasing and various social, cultural, political, economic and technological demands of its people'. Almaric (2007:137), defines development as a path of societal evolution that combines structural changes with improvement in people's welfare. From the above conceptualization, it can be deduced, that development is for people, and not people for development. For any development effort to succeed it has to be people oriented and focused.

Koinyan (1987:11) opined that, true development must mean the development of man, the unfolding and realization of his creative potential enabling him to improve his material conditions and living, through the use of resources available to him. He went further to say that, it is a process by which man's personality is enhanced, and it is that enhanced personality which is the moving force behind the socio-economic transformation of society. His argument therefore is that when the emphasis on development is on things, all human resources remain latent. Untapped potential and a society can be poor amidst the most opulent material 
resources. According to Olatunbosun (1975:39) Seers (1969) pointed out the following important questions in his discussion about development; what has been happening to poverty? What has been happening to unemployment? What has been happening to inequality? He went further to assert that if all three of these have declined from high levels, then beyond doubt this has been a period of development for the country concerned. If one or two of these central problems have been growing worse, especially if all three have, it would be strange to call the result "'development", even if per capital income doubled. Igbuzor (2006) says "even though there are different perspectives to development, there is a general consensus that development would lead to good change manifested in increasing capacity of people to have control over material assets, intellectual resources and ideology, and obtain physical necessities of life (food, clothing and shelter), employment, equality, participation in government, political and economic independence, adequate education, gender equality, sustainable development and peace'. He went further to claim that, this justifies the argument that the purpose of development is to improve people's life by expanding their choices, freedom and dignity.

Having examined different definitions and ideas put forward by different scholars on development, it is the position of this paper that development is the capability and ability of a nation to harness her-human, material and natural resources in other for the people to enjoy a sustainable standard of living and even development. Consequently, development shall be perceived in terms of well being of people and not the increasing national productivity alone. Development can be seen as improving the well being of people and expanding the choices and opportunities they have.

\section{THE POLITICS OF DEVELOPMENT BY THE COLONIAL POWERS IN NIGERIA}

The main objective of institutionalizing colonial rule in the colonies in Africa was to stabilize the polity so as to source for raw materials, cheap-labour and huge market for their products. The above determined the way they administered the people. The colonial authority in a country like Nigeria for example, used its divide and rule technique to administer the people, thereby making each group to see itself as unique and independent from the others. The comparative advantage principle was used and exploited to tap as much raw materials from the country as possible. Ake (1981:38), also opined that "the colonizing power ensured the specialization of the colony in primary production by adopting a system of quotas and tariffs which heavily favoured unprocessed primary commodities from the colonies". Hence, cash crop production was encouraged above food crop, in order for them to earn foreign exchange that would further empower them. Any form of production that was not of importance to them was played down on and discouraged. For example, the various cottage industries that were already in existence before the establishment of the colonial rule were dislocated as soon as they arrived through the various strategies and measures put in place. As put by Ake (1981:37), with colonization the Europeans took an interest in the development of an infrastructure, at least to the extent that it would serve their interest. They invested in primary production, exercised control over production and effected changes in the social structure which necessarily correlated to the type of economic development they wanted.

According to Ezeanyika (2010:110), "this profitable system was maintained by European powers because it prevented industrialization in the colonies". He went on further to say that, "they deliberately neglected the establishment of modern industries in their colonies because they gained more through the exploitation of local human and natural resources for the benefit of their metropolitan industrial estates. They also did not allow the colonized people to build industries capable of competing with their home industries".

The exploitative political economic activities of the colonizers led to the dependency syndrome suffered by the Nigerian people since after independence, whereby the nation's economy was and is still heavily dependent on the economy of the metropolis. The colonizing powers made sure that infrastructural development was to their own benefit once it will allow for easy transfer or movement of the raw material to the collection point. As observed by Ake (1981:43), "following the capitalist rationality of maximum output, they invested only in what had to and where they had to. Not surprising, the places in which colonialism fostered some development were in places which were convenient collecting centres for commodities, such as Kano; places from where the commodities could be shipped abroad, such as Lagos; places where climate was to the taste of Europeans and which could be used as administrative headquarters". He further said that, "these centres were a piece of Europe in Africa". By implication, development of the areas and sectors in the colony were selectively executed to the disadvantage of the latter. This brought about the dichotomy between the centres (cities) and the villages (periphery) where the colonized inhabited. Thus, the urban-rural divide which the post colonial Nigeria is still characterized. As a result of the politics of the colonial powers, the Nigerian colonial economy was short of linkages. That is, there were no forward and backward linkages due to the disarticulation of the economy as explained above. The Nigerian economy was an orchard with beautiful ripe fruits ready to be harvested by colonial government. 


\section{POST COLONIAL NIGERIA AND DEVELOPMENT}

By 1960, Nigeria gained her political autonomy from Britain. At this point, it was the expectation of the citizens that the country will turn around for good. They believed that the indigenes who have taken over the mantle of leadership had an answer to the way forward from where the colonizers left the country. It was observed that the different regions of the country experienced financial boom till the late 1960's from engaging in the production and export of agricultural produce they cultivated under colonialism.

However, as opined by Dodo (2009) the 1970's witnessed the abandonment of the above resources, with all attention focused on crude oil exploitation and export, which: now made product to become the main stay of the Nigerian economy, that is, a mono-product economy. Little did we know that it was going to be a carryover of the exploitative tendencies of the colonial era by the stooges they installed at independence? It is usually said that no one can give to another what he does not have. Consequently, all development programmes initiated at different points in time by different administrations could not be implemented to achieve results.

We shall take a look at some of them paying attention more on their level of success and the reason for not succeeding. In 1962, two years after independence, the first Development Plan (1962:68) was put in place. The Plan succeeded at first raising the rate of economic growth, secondly, to increase control of the economy. It was observed that $70 \%$ of total estimated expenditure went into direct productive sectors such as transportation, communication, electricity, primary production, trade, health and education (Dodo,2009). The above showed that, the first Plan was simply a continuation of the colonial development policy that placed emphasis on transportation and communication for obvious reasons, such as, facilitating the movement of raw materials out and finished products into the country. Because of the nature of the Plan, instead of moving the nation a step forward in her development effort in terms of achieving the three objectives for which it was put in place experienced some structural contradictions. These are rural poverty as against urban affluence, increased unemployment, surplus land with hungry people and finally, strong spirit of economic nationalism in the face of external dependence.

By 1970, a second Plan emerged after The Biafra-Nigeria civil war. As a result of the circumstance the nation was in at that point, the plan was then aimed at

$>$ Restoration and rehabilitation of economic activities affected by the war.

$>$ To achieve development based on available resources.

It was during that Plan period that the national objectives were specified as follows:-

$>$ A united, strong and self-reliant nation

$>$ A just and equalitarian society

$>$ A free and democratic society

$>$ A great and dynamic society

$>$ A land of bright and full opportunities for all citizens

The mining sector came into prominence in this Plan period helping to improve the exchange situation. This led to a growth rate of $6.6 \%$ or even over. In spite of what the nation experienced in the first Plan period, the rural areas that housed these important wells of wealth were neglected. The Plan period was still urban biased, created educational imbalance between the rural and urban areas, thereby reducing the standard of living in the rural over the urban areas. It could not bridge the gap between rural and urban dwellers. According to Leonard (2006), since the discovery of oil in the 1970's, the nation's economy has been a mono-economy because of the over dependence on the oil sector, which provides $95 \%$ of foreign exchange earnings, and about $80 \%$ of budgetary revenues. He further observed that, the oil boom accelerated massive migration that led to widespread poverty in the rural areas and collapse of basic infrastructure and social services since the early 1980's.

As opined by Onyimnatumba (2008), the oil boom was our doom, as it has killed other sources of revenue for the country. The rising death toll in Niger-Delta, both as a result of the environmental degradation and militarization of the zone is a reminder of how Nigerian leaders have turned a blessing into a curse. It will not be out of place to say that the social, economic and political menaces we experience in this nation are by products of the above Plan periods.

The third National Development Plan (1975:80) had the objectives to expand agriculture, industry, transport, housing, water supply, health facilities, education, rural electrification, community development and state programs. As a result of the emphasis on food production, so much money was plunged into realizing agricultural revolution and boom. River basins were established in the western, eastern and northern regions to meet up with all season production. Despite all the efforts put in the dream of surplus food followed by the general well being of the citizenry were dashed. As put forward by Nzimiro (1985:34), "the dichotomy between the urban and the rural was heightened as development plan emphasized the development of the urban enclaves". Nigeria that was once a large net exporter must import food. Beyond the Development Plans, there were other programmes initiated that were geared towards developing the nation. Programmes such as the Indigenization Decree of 1972, Operation Feed the Nation (OFN), Green Revolution in the 1980's, Import 
Substitution Industrialization, to mention but a few. The government that initiated the agricultural programmes for example, felt paying attention on agricultural development alone would mean development of the nation. But the result was that a few millionaires were made.

The above were all beautiful programmes initiated at different period of the nation's life by different regimes/administration. Each of the above ended up just like every other one because of the problem of implementation. This problem of implementation is not far from the nature of the Nigerian state, the type and the nature of the political/ruling class (described as anemic), the absence of structures, dependency culture that has enveloped the nation, the wrong value system that has permeated the nation, to mention a few. As observed by Dawodu (2008) "we all know that the only reason operation feed the nation failed was because it was meant to be Obasanjo's farm". For him the writers tagged OFN as 'Operation Fool the Nation'. Nzimmiro (1985) observed that the class character and content of the administrators of these institutions as criticized remain the same. As opined by Duru (2002) critics said that such efforts (OFN. green revolution, indigenization decree, etc.) in the past were merely cosmetic avenue for official corruption, self-aggrandizement and represented at best occasional effusion of a highly distorted sense of national importance, achievement and exaggerated cohesion. According to Ewegbemi (2007), Nigeria has gone from an agrarian society that was able to feed itself to a nation of importers of every food items. He further said that Operation Feed the Nation, the Green Revolution or the Mass Mobilization for Social and Economic Reliance (MAMSER) were all bureaucratic concoctions that were designed to make the people think that their leaders were working to lift them up, where as the real reason for these grandiose designs was to spread oil money around through official vehicles, overpaid and overfed permanent civil servants and ubiquitous contractors. With regards to the import substitution industrialization, Ajayi (1990), posits that, the effort at the import substitution industrialization failed to provide even one substantial manufacturing sector that could give the lead with the necessary growth.

The nation is still in starvation in the midst of plenty in spite of the oil boom. This is as a result of the carryover of the colonial administrative mentality by the ruling class. For example, at the point Nigerian leaders should have plunged the resources from excess crude oil sale into developing internal infrastructure; they concentrated on being the 'Father Christmas' of Africa. As pointed out by Dodo (2009:6), many analysts have described the outward show of affluence by the Nigerian government in the 1970's as playing the 'Father Christmas' outside, while her citizens suffered from abject poverty and gradual environmental degradation. Growth propelling ventures were abandoned for white-elephant projects which had little or no bearing with economic growth or development. According to Maier (2008:5), however deep Nigeria has sunk into a mire of corruption, repression and economic dilapidation, she remains one of the world's strategic nations. He went further to observe that designed by alien occupiers and abhorred by army rule for three quarters of its brief life span, the Nigerian state is like a battered and bruised elephant staggering towards an abyss with the ground crumpling under its feet. Should it fall, the impact will shake the rest of West Africa. The Nigerian political economy is being bedeviled with ethnic and religious divides.

\section{CONCLUSION}

Going back in history, it will not be out of place to say that the political economy of the Nigerian society has all these years been hinged on the self interest of the leaders. At the point Nigerian leaders should plunge the resources from excess crude oil sale into developing internal infrastructure; they concentrated on being the "Father Christmas' of Africa by declaring Africa the centre piece of Nigeria's foreign policy. They got into squander mania. As pointed out by Dodo (2009:8), many analysts have described the outward show of affluence by Nigerian governments in the 1970"s as playing the 'Father Christmas" while her citizens suffered from abject poverty and gradual environmental degradation. Since after independence, it is very clear that Nigeria has always had visionless leaders, who have PLUNGED THE country into economic, social and political woes that we are struggling to come out of. The leadership of this country has been known for reckless spending, over-invoicing, and diverting of state finances into their personal accounts.

Most of the development programmes initiated since after independence have not succeeded because of lack of drive to effectively implement them and the absence of the appropriate infrastructure needed for such programmes. For example, most of the roads and ports are in poor shape. Powers that propels development is hard to come by. Growth propelling ventures were abandoned for white-elephant projects, which had little or no bearing with economic growth or development. Our leadership is fund of putting the cart before the horse. For every programme, the nation experienced a 'near success' syndrome. It has remained worrisome, that for many years after Nigeria's independence and considering her abundant human and material resources of great economic value, Nigeria is still not close to the threshold of socio-economic stability and development. 


\section{RECOMMENDATIONS}

There is need for value re-orientation. The minds of the citizens should be disabused from xenocentric tendencies, consumption and import-oriented cultures. This will help citizens begin to look inward for their needs and be patriotic, thereby improving the economy and the standard of living of the people.

The government should pay more attention on building structures that would lead to enhanced and sustained development. The issue of power is of great importance for any nation that wants to develop. All activities revolve around power for sustainability.

The nation is in dear need of a people-focused, visionary, purposive, targeted, determined and fearless leader and not ruler; a leader that will lead us into industrial revolution rather than ethical revolution.

There is also the need for a productive and consciencetized political class with the interest of the nation at heart (i.e. patriotic leaders).

\section{REFERENCES}

[1] Ajayi, I. (1990). The Trapped Economy (Nigeria: A Non-ideological Strategy for Self-reliance). Ibadan: Heinemann Educational Books.

[2] Ake, C. (1981). A Political Economy of Africa. U.S.A. Longman.

[3] Almaric, (2007). Societal Transformation: Growth, Poverty and Recognition. Development, 50 (51): 136 $-147$.

[4] Aregbeshola, R.A. (2011). The Political and Social Dynamics of Nigeria: A Synopsis. Asia Policy Brief. Number 39, February 2011.

[5] Bohon, S., Dahms, H.F., Dandaneau, S. P., Freu, R.S., Gellert, P. Jalata, A. \& Shefner, J. (2003). Political Economy. Tennessee: The University of Tennessee, College of Arts and Science; Development of Sociology.

[6] Dawodu, A. (2008). Owners of Nigeria. http://www.dawodu.com/ oduyelab.htm.

[7] Duru, R.U. (2002). Poverty Alleviation Programme and Development of Small and Medium Scale Enterprises. Prospects for Poverty Alleviation in Rural Nigeria. Journal of Management and Development Studies 1(1): 159 - 163.

[8] Eboh, E.C. (1999). Political Economy of National Development. Issues and Perspectives. Lagos: Academic Publications and Development Resources Ltd.

[9] Ewegbemi, O, (2007). Nigerian's Dependence on Oil: A Course on Economic Nationalism. http://www.dawondu.com/ewegbemi/htm

[10] Ezeanyika, S.E. (2010). International Political Economy: Themes and Perspectives. Owerri: 4th Ed. Development Studies Research Group (DESREG) in Collaboration with Gabfory Publishing Ltd.

[11] Groenwegen, P. (2008). Political Economy and Economics. The New Palgrave: A dictionary of Economics, 3:904-07.

[12] Henderson, T., (2015). Why Study Political Economy? http://ppesydney.net/why-study-political-economy (Accessed 7 November 2015.

[13] Ibe, S.O. (1989). Women Participation in Rural Development. The Case of Aboh Mbaise LGA of Imo State in Roles and Paradigms in the Rural Development of Nigeria. Owerri: Karto Press.

[14] Igbuzor, O. (2006). Review of Nigeria Millenium Development in Nigeria Goals. http://www.dawodu.com/igbuzor/htm.

[15] Koinyan, A. (1987). Arts and National Development: A Sociological Overview. Nigerian Journal of Development Alternative 1(1): $10-15$.

[16] Luqman, S. and Lawal, F.M. (2011). The Political Economy of Oil and the reform Process in Nigeria's Fourth Republic: Successes and Continue Challenges. Research World, 1192): 59-76.

[17] Leonard, T.M. (2006). Encyclopedia of the Developing World. http://books/google.com/books?id (Accessed 20 October 2015).

[18] Maier, C.S. (2008). The Political Economy Approach. http://en.wikipedia.org/wiki/political-economy (Accessed 15 November, 2015).

[19] Njoku, N.L. (1997). Studies in Western Imperialism and African Development. Owerri: Tonyeben Publishers.

[20] Nzimiro, I. (1985). The Green Revolution in Nigeria or Modernization of Hunger. Lagos: Zim Pan-Africa Publishers.

[21] Okoye, M. (1985). Even Development: Problems and Solutions. In: Nwosu, E.J. (ed) Achieving Even Development in Nigeria: Problems and Prospects. Enugu: Fourth Dimension Publishing Co. Ltd.

[22] Olatunbosun, D. (1975). Nigeria's Neglected Rural Majority. Ibadan: Oxford University Press.

[23] Oyimnatunba, C. (2008). Nigeria at 48: Still Perambulating and Groping for the Way. Lagos, Nigeria. 